\title{
The Strategic evolution of Aer Lingus from a Full Service Airline to a Low Cost Carrier and finally positioning itself into a Value Hybrid Airline.
}

Aer Lingus has been a unique airline as it transitioned from a full service airline to a low cost carrier and is currently positioned as a Value Hybrid. It has co-existed with Ryanair for decades and faced numerous macroeconomic events that had a cascading effect on its commercial enterprise. Its transformation into a Value Hybrid in 2010 showcased its differenciation against Ryanair as it produced value-adding and consumer driven product differentiation beyond the basics of the low cost carrier product. The research aims to uncover the various strategies that were applied to structurally re-engineer the carrier. Analytical insights accompanied by the views of leading industry experts uncovered the key pillars underpinning Aer Lingus' turnaround which precipitated a subsequent buyout from IAG. These strategies included: strict adherence to capacity displine; relentless cost control and value-adding product differenciation; innovative partnerships including contract flying; and most importantly, the re-engineering of its Dublin based hub airport. A visionary masterplan for the hub was fabricated to capitalise on Ireland's geographical positioning which targeted the traffic flows between UK/European and North American destinations through its synchronised connection network at Dublin.

Keywords: Aer Lingus, Hybrid, Dublin hub, North Atlantic

Aer Lingus' 80 year history has been in a constant state of flux tethering on the brink of bankruptcy in 1993, 2001 and 2009. Its airline business model was encapsulated as a Full Service Network Carrier till 2002, evolving thereafter into a Low Cost Carrier as it cohabitates with Europe's lowest unit cost provider (Ryanair) until 2008, after which, it began adapting its business model towards that of a Hybrid ${ }^{1}$ airline where it adopted certain fundamental LCC principles while retaining the core elements of network airline. Figure 1 summarises the cyclical financial turbulence endured by Aer Lingus from 1980 to 2014, a period through which it encountered the most challenges as deregulation triggered a new competitive era in an ever challenging macroeconomic environment. Since its inception up to 2014 , it had ammassed an overall net loss of $€ 78$ million after 80 years in operation. Yet it became International Airlines Group's (IAG) strategically most important newest member in 
2015 and a carrier highly valued by IAG, particarly since it began developing its hub as a mechanism to transfer traffic from UK and EU airports to North America (Walsh, 2015). This paper aims to uncover the principle strategies that were applied to structurally re-engineer Aer Lingus to overcome its numerous challenges over the decades and to disclose the key underpinning strategies of its Value Hybrid business enterprise that made it such an attractive aquisition proposition for an IAG buyout.

\section{Insert Figure 1}

\section{Background of Aer Lingus}

Aer Lingus: Its inception to 2001 - A Full Service Network Carrier

Aer Lingus was established in 1936 as Ireland's national airline. For decades, Ireland had one of the most stagnant aviation markets in Europe and it was perceived as an unattractive destination for new entrants. Agriculture remained the bedrock of employment and economic development; while data from the Irish Central Statistics Office (2015) reported that unemployment levels reached $17 \%$ in the 1980 s while a $68 \%$ marginal tax rate prompted mass emigration to the US and to the UK. In addition, Ireland's tourism potential was suppressed by the continuing violence in Northern Ireland ${ }^{2}$, as the country as a whole was perceived to be in conflict. Tourism overall to Ireland, had been stagnant at 2 million visitors a year for two decades. Academics, classified the Irish flag carrier with all the symptoms and characteristics of 'Distressed State Airline Syndrome', an acronym linked with inefficiencies and bureaucracy stemming from State ownership (Doganis, 2001 and Barrett, 2006). The Irish incumbent suffered from an array of complications including: loss making (32 loss making years from 1936 - 2014); strong unions (SIPTU, IMPACT and TEEU), which represent approximately $97 \%$ of Aer Lingus employees; overstaffing with 6,000 staff to carry 2.0 million passengers in 1977/78 (Barrett, 2006) - with no change over the next decade; bureaucratic management (Skinner and Cranitch, 1990); no clear development strategy (developed 40 non airline businesses (Share, 1986); poor service quality (high fares bundled with standard service, Barrett, 2006)); together with constant government interference such as 
enforcing a compulsory Shannon airport stopover which prevented direct transatlantic flights to and from Dublin.

In 1986, Ireland became the first European country to allow a new market entrant to compete with its national airline on its major route, 11 years before EU deregulation in 1997. This new challenger became known as Ryanair, which would forever change the dynamics of Aer Lingus and the EU short haul market. Barrett (1997) declared that Ryanair immediately offered fares more than $50 \%$ below the tariff of that charged by the Irish incumbent, while O'Connell and Williams (2005) calculated that Aer Lingus' unit costs (in terms of CASK) were double that of Ryanair, making it very difficult for the flag carrier to compete.

By the early 1990s, the Irish incumbent faced a dual challenge because Ryanair continued to encroach on its markets and due to the first Gulf War, which plunged Aer Lingus into a deep financial crisis, whereby it lost IR£116 million in 1993 and had debts accumulating IR£540 million, while transporting just 6.6 million passengers - this was worse than all other European airlines, with the exception of Olympic, while Swiss and Sabena had already declared bankruptcy. In an effort to restructure the losses, a rescue proposal termed the Cahill plan was inaugurated to reduce the workforce and restructure the business, while the Government injected IR $£ 175 \mathrm{~m}$ ( $£ 90 \mathrm{~m}$ for redundancy payments with the balance used to reduce debt) - under new EU laws, this was the last time that Aer Lingus would receive any further subsidies. Wallace et al (2006) indicated that Industrial relation issues with the unions over redundancies were essential to this package as it endorsed that staff attrition of 1,500 employees accompanied the bailout, while the Government discredited the Aer Lingus board for their irresponsible management that incited its impending difficulties (House of the Oireachtas, 1993). This package saved Aer Lingus. Over the following years, Aer Lingus capitalised on growth levels in the industry due the ongoing strong worldwide economic prosperity, while its earlier cost cutting measures were also contributing positively to its financials as it generated close to $€ 120$ million in net profit from $1995-2000$.

\section{Aer Lingus: From 2001 to 2009 - A Low Cost Carrier}

The global macro effects of the early 2000s spurred a series of catastrophic events that had a cascading effect on Aer Lingus. Principle among the factors that had precipitated the airline's early decline were scares over the Foot and Mouth disease in the UK and Ireland, which led to a major drop in traffic in one of its most important markets as UK traffic accounted for 3.6 
million of the 6.9 million total traffic carried in 2000. Meanwhile, its profitable North American operation was plunged into disarray as the technology stock crash in 2000, coupled with the 9/11 attacks, pushed the carrier deeper into financial crisis. The sudden fall in US traffic had disastrous consequences for Aer Lingus, which earned around $40 \%$ of its revenues and $50 \%$ of its profits from its North American operations (Aer Lingus, 2002). Meanwhile, over half of Aer Lingus' short-haul routes were now in direct competition with low cost carriers out of its Dublin hub airport, in contrast to Lufthansa where only $12 \%$ of its European routes were in direct competition with budget carriers at Frankfurt Main (O'Connell, 2007). With the North Atlantic market in chaos and continued pressure from Ryanair, the airline lost $€ 140$ million in 2001 and its financial situation was rapidly deteriorating. O’Connell and Williams (2005) reported that it was losing €2.5 million per day by November 2001.

Willie Walsh took the helm of Aer Lingus in October 2001. The new management team realised that the low-cost sector had created a radical and irreversible downward shift in ticket prices. It needed to vigorously remove more cost layers and adopt as many low-cost features as possible while retaining some essential differentiators such as primary airports and connectivity for example, in order to differentiate itself more effectively from Ryanair. Walsh etched out a survival plan which required cost reductions to the magnitude of $€ 344$ million, spanning from 2001 to 2003, which represented 30\% of the 2001 cost base which were required in order to restructure the airline and mount a formidable challenge to Ryanair. In tandem, it implemented six core strategies that underpinned Aer Lingus' turnaround that included: a fare reduction of $37.5 \%$ on short haul routes coupled with a $25 \%$ reduction for the long haul; strengthened the network footprint togther with standardising to a single fleet type; realigned the human resource threshold while enhancing productivity; expediated its distribution mechanism to an online platform, retained the Aer Lingus' differentiated products; together with effective advertising (O'Connell, 2007). These policies transformed the carrier's finances from a loss of $€ 139$ million in 2001 to a profit of $€ 69$ million by 2003 .

Mannion succeeded Walsh as CEO in mid 2005 whose principle mission was to prepare and float the national carrier on the stock market ${ }^{3}$. The proceeds from the sale of the new shares were intended to be used to finance the airline's fleet expansion, as well as a once-off contribution to its pension fund ${ }^{4}$. Shortly after the IPO, Ryanair ${ }^{5}$ built up equity stake of $29.82 \%$ creating a difficult ownership structure and a very disruptive influence to Aer Lingus management. The severe economic recession and financial crisis of unprecedented magnitude, that originated in the US in 2007 rapidly spread to other countries 
including Ireland. Waldron (2016) argued that the bursting of the finance-led property bubble resulted in the bailout of the Irish banking system (€64 billion), which in itself resulted in the subsequent bailout of the Irish State by the IMF, ECB and European Commission (€67 billion). The reliance of the Irish economy and banking sector on the domestic property market was to be exposed, with disastrous economic and social consequences. Aer Lingus was heavily exposed with net losses of $€ 108$ million for 2008 , followed by another net loss of $€ 130$ million for 2009. Its Return On Capital Employed (ROCE) fell from 3.9\% in 2006 to $11.5 \%$ by 2009 indicating an alarming inefficient use of capital, while its gearing ratio which is a measure of financial stability significantly deteriorated from $56.7 \%$ in 2006 to over $80 \%$ by 2009. Meanwhile the critical financial metric of its Cash balance posed major concerns as it dwindled from around $€ 1$ billion in 2006 to $€ 636$ million by 2009 . Aer Lingus' chairman Colin Barrington described the situation as follows 'Aer Lingus is facing its most difficult period in its history' at its 2009 AGM (Buyck, 2009). Indeed, the Irish flag carrier was again in the fight of its life.

The final and most critical turnaround strategy for Aer Lingus - the formation of a Value Hybrid model.

Christoph Muller acquired the position of CEO in mid 2009 and by then the airline's first-half 2009 losses had quadrupled - it was already battling high fuel costs and was faced with the twin threat of an uncompetitive cost base together with a weak revenue climate that was escalating due to Ireland's financial crisis. The authors conducted expert ${ }^{6}$ interviews with industry, consultancy and academic personnel who were very familiar with the carrier's operating environment. They concluded that the major challenges facing Mueller were: the positioning of the Aer Lingus business model; cost base; employee morale; revenue/traffic generation; future of the transatlantic market; unions; competition; recession; together with the pension deficit. There was real confusion within the financial markets and general public as to the positioning of Aer Lingus with terms such as low cost, twin-track, hybrid and valuecarrier being used. Tarry (2015) and Tiernan (2015) indicated that the airline had gone too far to the LCC side of the business model continuum, while Corneille (2015) commented that the long haul product was not good enough to be considered truly full service. De Wit and Zuidberg (2012) specifically referred to Aer Lingus as being a Hybrid combining low cost European routes with full service long-haul wide body operations, while Klophaus et al. 
(2012) reiterated that Aer Lingus was a hybrid carrier but had dominating LCC characteristics. Mueller (2014) delineated that Aer Lingus had evolved into a 'Value' Hybrid enterprise as it needed to emboss an upmarket polished trademark that differentiated itself from the insignia of LCCs. It sought to combine the best elements of LCCs with the option to upgrade to the features of a full service airline, whose characteristics are portrayed in Table 1.

\section{Insert Table 1}

The expert interviewees also commented that there was a need to unite the long haul and short haul aspects of the business. The transatlantic was undeveloped, with Fagan (2015) describing the north Atlantic as mostly point-to-point traffic. Barrett (2015) stated that Aer Lingus had a strong tradition of trade union dominance, while Tiernan (2015) referred to the multiple number of different unions associated with the flag carrier - in the 1980s there were 30 different unions. Doganis (2014) and Bisignani (2013) concurred that Aer Lingus was not large enough to compete effectively against the Majors in the long haul markets and did not have the unit cost advantages to compete effectively against the LCCs in the short haul markets.

Mueller set out the following strategies to turnaround Aer Lingus that would formulate an effective business model and make it an attractive buy-out target for IAG.

\footnotetext{
i. Capacity management

ii. Cost based reduction and value adding processes (Product developement)

iii. Partnerships

iv. Connectivity and network developement
}

\section{Capacity management}

Mueller's key strategic pillars were underpinned by its strict capacity displine on both its long and short haul network - Aer Lingus remained unwavering in matching capacity with demand which significantly improved load factors. Its long haul operations on the North Atlantic date 
as far back as April 1958 when it operated the Super Constellation and carried almost 15,000 passengers in its first year of operation (Cronin, 2011). Its current long haul operations are focused solely on the North Atlantic, but it did briefly operate to Dubai in 2007. Aer Lingus was one of the last remaining meaningful independents commanding around $2 \%$ of the estimated 74 million passengers travelling annually between Europe and North America. The capacity between the two continents remains tightly controlled by a cartel of alliance partners who possess antitrust immunity that subsequently control around $86 \%$ of the passenger share (O'Connell, 2015). Brueckner and Proost (2010) state that these antitrust joint ventures involve the full exploitation of economies of traffic density on the hub-to-hub route. Dobruszkes and Van Hamme (2011) noted that Aer Lingus reduced its overall seat capacity by almost one-fifth between January 2008 and January 2010, mostly originating from its long haul operations.

Seasonality is an inherent problem for Aer Lingus and its 2013 annual report reflects the reasoning as it is dominated by passengers travelling for leisure reasons, which represents $77 \%$ of its customer base, with holiday traffic representing $43 \%$ which is highly seasonal, followed by Visiting Friends and Relatives 28\%, which is also seasonal in nature (Aer Lingus, 2013). Figure 2 displays the evolution of seasonal ASKs flown and shows the continous oscillating motion throughout the calendar year which correlates with the undulating load factor in both short and long haul markets. It illustrates the long haul operation reductions to 2010 and the subsequent upscaling of the capacity by around $12 \%$ each year to present day, which was attributed to the growing passenger traffic that was flowing through the Dublin hub. The yield barometer was thriving due to strengthening load factors and capacity management. Meanwhile in the short haul market, Aer Lingus also reduced its capacity in 2009/10, but to a lesser degree than in the long haul sectors. By 2014, it commanded around $44 \%$ of the Ireland to Europe market, where it assigns around $20 \%$ of its short haul seats to the bespoke London Heathrow to Dublin circuit as the route attracts a disproportionate share of high value business traffic. Here it serves to differenciate itself from Ryanair with its frequency proposition of 13 flights per day. Aer Lingus is the $4^{\text {th }}$ largest operator by movement at Heathrow, where it controls 23 slots, behind: Luthansa (25); Virgin Atlantic (34); while BA dominates with 350 slots - bellwether Deloitte assigned a valuation threshold of between $€ 770$ million and $€ 925$ million for the ensemble of Aer Lingus' Heathrow slots (Irish Times, 2015). The importanace of the Heathrow - Dublin route is evident, as it is the busiest air route in Europe (second busiest in the world, after Hong Kong - Taipei) amassing 4.5 million passengers in 2015 with 19 daily flights. The closure of the 
Gatwick base allowed for more frequencies to be allocated to key city-pairs as managments' attention began to emphasise the importance of 'frequency' when building its hub (Fagan, 2015).

\section{Insert Figure 2}

\section{Cost based reduction and revenue generating products}

Figure 3 shows that Aer Lingus unit costs compares favourably relative to other flag carriers, but sustains higher costs when paralleled to low cost carriers - a reflection of its hybrid business model. Aer Lingus has a 28\% unit cost advanatge over Lufthansa, while easyJet has only a $16 \%$ improvement. It is clustered in the same proximtely as Air Berlin, another carrier running an explicit hybrid model but with slighly more advantageous unit costs. Table 2 illustrates the unit cost evolution over a five year period. Three cost categories in particular have escalated significantly over the years which include: fuel; airport charges; and ground charges. Firstly, Aer Lingus fuel hedging strategies occillated widely from a high of $77 \%$ of total uplift, hedged at $\$ 76$ per tonne in 2010 to a low of $61 \%$ at $\$ 97.5$ per tonne by $2014-$ the carrier's low hedging policy coupled with purchasing the remainder of its fuel requirements at current maket prices, significantly increased the cost creep (Aer Lingus; 2009, 2010, 2011, $2012,2013,2014)$. Each US\$1 fluctuation in the price per metric tonne of fuel could impact Aer Lingus' fuel expense by around $\$ 500,000$ before any currency or hedging considerations are taken into account. Currency fluctuations also escalated its fuel expenditure as well as its other USD-denominated costs as the US dollar for 2014 strengthened by $12 \%$ against the Euro.

Secondly, One of Aer Lingus' principle differenciators over LCCs is its dependence on serving primary airports which exercise market power due to their slot restrictions and excess demand on its infrastructure. A research report by Aviation Economics (2016) cites that airport charges at the largest 21 European Airports have increased by $80 \%$ since 2005, with the average passenger charge at Irish airports rising by $97 \%$ from $€ 10.43$ per passenger in 2005 to $€ 20.54$ by 2014 . Thirdly, ground charges at the primary airports that Aer Lingus serves has increased by $50 \%$ from 2009 to 2014 , reaching almost $€ 153$ million in 2014 , 
which is excessive given its maintenance costs amount to just half this expenditure (Aer Lingus; 2009 to 2014).

A cost saving plan termed 'Greenfield' was instigated by the senior management team in 2009 which was designed to remove $€ 97^{7}$ million over 3 years, which translated to the removal of $7.4 \%$ from its cost base, which was ambitious considering that a mandate of $3.1 \%$ reductions were set for Air France and 2.6\% for British Airways. In order to rightsize the airline, the plan included 863 voluntary job redundancies as well as pay cuts to those earning over $€ 35,000$ per year, while a three year pay freeze was introduced for others (CAPA, 2009). Cabin crew productivity has notably increased from 700 hours per month in 2009 to 850 hours by 2011 . The $13 \%$ fewer staff aggregated into savings of $€ 53$ million lowering the CASK per staff from 2009 to 2011 as shown in Table 2.

During this period of cost cutting, the carrier also innovated its pricing strategy by unbundling its fare categories in order to reach a wider passenger segment by supplying different products at various price points via an a-la-carte mechanism, allowing it to compete more effectively with Ryanair. It introduced 3 customised fare options during 2010 titled 'Low', 'Plus' and 'Flex' with the 'Low' fare option being specific for carrying cabin bags only, while the 'Flex' captured all of the products associated with a business traveller including interchangeable tickets and full refunds. The 'Plus' fare choice allowed a passenger who was on travelling for vacation for example to include hold-baggage, seat selection and the ability to earn frequent flyer points. The management team continued to focus on ancillary revenues as a platform to boost income streams given their Hybrid positioning and by 2014 it garnered $€ 19.14$ per passenger up from $€ 16.75$ per passenger in 2009 , while McCabe (2015) reports that $96 \%$ of this income is profit as the associated cost is negligible to Aer Lingus. By 2014, it accounted for around $12 \%$ of its revenues compared to just $1.9 \%$ by British Airways (Ideaworks, 2015). Its innovation footprint expanded when it commenced selling business class meals to economy class passengers on transatlantic services together with personalised merchandising capability. The carrier also vertically integrated its Aer Lingus' Holiday division into its website where the platform allows a customer to combine multiple travel components such as hotel accommodation and airport transfers where consumers become their own travel agents by building a tailor-made package that suits their specific requirements. Aer Lingus' cargo business is also an important revenue contributor netting over $€ 46$ million in 2014. It does not operate dedicated freighter aircraft, but instead utilises the available hold capacity of the passenger aircraft fleet where it carries cargo on both long haul and where turnaround times permit on short haul sectors. It carries almost 3.5 
times more cargo on its long haul routes than its short haul and earns approximately $80 \%$ of cargo revenue from the long haul sectors.

For the onboard product of its long haul fleet of A330s, it installed flatbeds with 79 inch seat pitch and 20 inch seat width, comparable to Delta's and American's A330s, while it further differenciated itself against its US counterparts with onboard WiFi. Other business product features included a new pre-dining service, a new lounge in New York and an arrivals lounge at Dublin, together with a redesigned Frequent Flyer Program that is specifically customised.

The combination of cost cutting, capacity control, revenue generation and product enhancement significantly impacted the overall yield per kilometre for Aer Lingus reaching 7.6 cents in 2014, up by over one-third when compared to 2009 levels.

Insert Figure 3

Insert Table 2

\section{Partnerships}

The importance of partnerships to the Aer Lingus strategic turnaround was of paramount importance (Mueller, 2014). It developed a bipartisan structure being split into code share agreements and innovative partnership agreements.

The flag carrier's withdrawal from the Oneworld alliance in 2007 created a network void and consequently it needed code share partnerships as many passengers needed to travel 'beyond' the gateway cities served by Aer Lingus. Consequently it rapidly established a new spectrum of code share agreements with independent and alliance affiliated carriers from 54 partners in 2009 to 98 by 2015. The importance of the US market was apparent as United Airlines and JetBlue each had $40 \%$ of the code share agreements by 2015. JetBlue's transactions were via its New York and Boston bases, however Bilotkach (2007) researched that demand is very price sensitive when a low cost carrier feeds domestic traffic to international routes, inferring that the yield generated by Aer Lingus through this partnership was lower than that provided by a full service airline. The Irish incumbent expanded its onward reach from its Chicago O'Hare gateway with United Airlines. It had no territorial 
network coverage of Asia or the Middle East, but it cultivated such an opporutunity with Etihad Airways who had forged an equity partnership totalling almost 5\% by 2014 and accounted for a further $11 \%$ of the code share agreements. This was significant as it allowed Aer Lingus to gain traction into the traditionally strong traffic flows between Ireland and Australia.

It then began to forge new innovative partnerships of an entrepreneurial nature which were not commonplace in the airline industry, through a series of 'Contract Flying' collaborations with United Airlines, Virgin Atlantic and Novair, while it simultaneously fabricated a unique franchise partnership with Aer Arran. The first such flying contract agreement was orchestrated with United Airlines to operate from Washington to Madrid in the midst of the deep recession in early 2009 - Aer Lingus seized on the opportunity provided by the EU/US Open Skies legislation which was the first of its kind involving a US carrier. Mannion (2015) concluded that this had the dual impact of outsourcing its excess long haul capacity (including Aer Lingus pilots) while at the same time tackle the strong seasonality problem inherent in Aer Lingus markets - the service continued to 2012. A similar type of ACMI (Aircraft, Crew, Maintenance, Insurance) wet lease contract was iniatiated with Virgin Atlantic in late 2012, where the Irish incumbent provided four A320s, which were used to connect UK provincial airports with large catchment areas to Heathrow in order to connect to Virgin's long haul operations in the livery of 'Little Red' (Moores, 2013). The risk to Aer Lingus was negligible as it bore no involvement in the commercial operation (Mueller, 2014). In another attempt to tacke the strong seasonality faced by Aer Lingus, a further contract flying assignment was secured in April 2013 involving an A330 outsourced to Novair, a swedish Charter for 3 Winter seasons from Winter 2013 to Winter 2015 (CAPA, 2013). This was a key strategic move as it kept the expensive widbody asset in service, generating revenues during the trough period of the lowest yearly demand.

In 2010 Aer Lingus developed a franchise with Aer Arann (now called Stobart Air), which was Ireland's only regional airline predominating serving regional airports in the UK, as well as Irish Public Service Obligation (PSO) routes with a standarised fleet of 16 ATR aircraft carrying almost 900,000 passengers. The aim of the regional carrier was to connect secondary UK cities to Aer Lingus' Dublin hub for onward connectivity, particularly to the USA. The partnership was extended for 10 years in 2013 in reponse to its success and furthermore Aer Lingus entered into a 33\% ownership of 8 new ATR aircraft. Denton and Dennis (2000) asserted that there are significant benefits to the franchisor such as: being an inexpensive way to extend the brand; a means to continue to operate thin routes; a way to 
increase frequency; and as an instrument to generate feed traffic - all of which were incorporated. Aer Lingus also engaged the franchise to trial thin routes as a testbed before it inaugerated a low capacity A319 which allowed it seamlessley bridge the transition from a 65 seat ATR-72 to a 148 seat A319, minimising risk of route failure (Moores, 2013).

Aer Lingus also implemented the unique strategy of simultaneously insourcing capacity from outside its own aircraft metal by partnering with Air Contractors to operate 3 B757s on Transatlantic routes (Kaminski-Morrow, 2013). This allowed year round operations from Shannon and also provided an aircraft to operate a new route from Dublin to Toronto as they were ideally suited to thin low demand routes. Similar to Aer Arran strategy, the costs associated by incorporating a different aircraft type into the fleet were not borne by Aer Lingus, while unions were appeased as one pilot on each 757 were sourced inhouse. Meanwhile in a bid to maximise the benefits of strong summer demand on the North Atlantic, a Boeing 767 was concurrently leased from US based Omni Air International for 12 weeks (June to August) (CAPA, 2015).

\section{Developing the Hub and Engineering its Connectivity}

All of the experts concurred that re-enginerring Aer Lingus' hub was the key linchpin that underpinned its turaround as it could capiatlise from Ireland's advantageous geographical position by capturing some the traditional traffic flows between Europe and North America. (Mueller, 2014; Doganis, 2014; Walsh, 2015). This made it such an attractive proposition for an IAG buyout.

Aer Lingus' rudimentary Hub in 2008

Flag carriers that already operated rudimentary wave-system ${ }^{8}$ at their home base in the early 1990s began optimising their wave-structures which entailed amongst other things a tighter schedule coordination of arriving and departing flights and an increase in the number of connection waves. For decades no visionary masterplan was executed to capitalise on Ireland's geographical positioning, while Aer Lingus under the auspices of a Governmentowned mindset rigidly steered the carrier to operate as a point to point airline to serve Ireland and only Ireland. Burghouwt and de Wit (2005) stated that Air France had four departing 
sequences at Charles De Gaulle per day but that Aer Lingus had no such hub structure in place and stressed that the carrier had a weak schedule. Aer Lingus had become an Irish 'vehicle' for immigration, tourism and trade but it was not optimising its commercial opportunities, unlike its European counterparts that had developed hub connectivity between intercontinental flights and their European feeder network. Its long haul operations were there to serve the main population centres of Irish expatriate communities in New York, Boston and Chicago. The Shamrock logo on the aircraft tail fin is a firmly intertwined brand embedded through deep layers of Irish society symbolising heritage, pride and used as leverage for its affiliation with Ireland. The brand also reached out to the 36 million Irish Americans who were naturally drawn to fly with the nostalgia of Aer Lingus.

The undeveloped Aer Lingus bank structure in 2008 is shown in Figure 4. The outbound flights to the USA were not sequenced to maximise connections, for example the 09.40 departure to San Francisco could only be linked with one flight from London Heathrow and another from Manchester, as the other incoming UK/European flights were not co-ordinated in order to make the synchronised connection. Meanwhile, only the morning New York and Boston flights arrived into Dublin before the main UK/EU departure waves from Dublin. The opportunity to develop a hub configuration was noticeable in 2008 as Aer Lingus offered 61 weekly summer flights across the North Atlantic and commanded almost 53\% of the seat capacity. It had not engineering an architectural link to interweave its short haul network to its long haul at Dublin Airport - this was the linchpin that significantly weakened the carrier. Burghouwt's (2007) stated that a genuine hub must exist spatially and also have a temporal aspect reinforcing that Dublin was not a hub.

\section{Insert Figure 4}

\section{Engineering the Hub Connectivity platform}

From 2010 to present day, the new Aer Lingus management team formulated a commercial business model template that would re-engineer the carrier's network by utilising Ireland's advantageous geographical position as being the most westerly peripheral European country with the objective to create a seamless network linkage between Europe and North America. Other similar mid-sized airlines had already implemented a successful 'focused' strategy 
based on geography such as Finnair who maximised their position as the shortest distance between Europe and North Asia, while TAP Air Portugal specifically focused its long haul operations in connecting its former colonial state of Brazil to Portugal with 77 frequencies per week to 9 Brazilian cities by 2015, while COPA acts as a connector between the US to South America corridoor through its hub at Panama city. A 'blueprint' framework was unfolded to develop a new pivotable hub, capable of redistributing traffic from Europe to North America and vice versa via Dublin airport. The vision was credible because there were 67 European airports with links to US/Canada, while 45 US/Canada airports had links to Europe in 2015.

Ireland's most important country aviation markets would be the key underpinning consideration when reengineering the hub as it had to capitalise on these potential traffic flows. These country markets in terms of the total number of departing seats from Ireland during July 2015 were as follows: United Kindom $(633,618)$; Spain $(247,765)$; United States $(175,337)$; France $(118,767)$; Germany $(107,952)$; Italy $(84,995)$; Portugal $(64,541)$; Poland $(47,925)$ UAE (44,230); Holland (42,921); Belgium (29,424); Switzerland (22,871); Canada $(21,620)$; Denmark $(15,032)$ and Czech Republic $(12,441)$. Clearly the UK was to be the backbone in developing the Dublin hub as British Airways only served 7 regional UK airports (Aberdeen, Belfast city, Edinburgh, Glasgow, Leeds Bradford, Manchester and Newcastle) from London Heathrow despite the UK having the largest number of air passengers in Europe totalling 241.3 million for 2014, followed by Germany with 208.5 million (UK, CAA 2015; ADV, 2015). KLM and Air France for example served 21 and 13 UK airports in 2014 from their megahubs at Amsterdam and Paris respectively, where a sizeable portion of this traffic would connect to onward destinations. A Dublin hub would eliminate the 'backtracking' nature for passengers, travelling onto North America that a transfer in Amsterdam or Paris would involve due to its geographical positioning. Doganis (2014) argues that this would be a core competency in developing the Dublin hub. SuauSanchez et al. (2016) analysed that 52.5\% of UK passengers in 2013 were travelling on long haul flights from UK Regional airports via an intermediate hub to North America, but just $2.9 \%$ of UK regional traffic that was bound for North America transited through Dublin. Aer Lingus' regional franchise Stobart Air provides services to these UK regional airports and it has spread its network footprint extensively from Dublin since 2009 where the number of destinations had doubled to 16 by 2015. For key cities such as Manchester and Birmingham, both Aer Lingus and Stobart Air operate, as frequency became a paradigm focus to boost the connectivity permutations at the Dublin hub. The Irish capital also becomes an attractive 
option for UK based passengers journeying to overseas destinations as they are levied with an additional Air Passenger Duty ${ }^{9}$ tax that is proportioned by the distance travelled and class of travel, but this can be largely escapable when the trip is undertaken through a European hub. However the Aer Lingus proposition becomes exponentially attractive because US bound passengers can clear US Border Customs and Pre-clearance at Dublin's new T2 ${ }^{10}$, allowing them direct entry into the US, bypassing the lengthy Homeland Security - it is the only such facility in Europe outside of Ireland's other US gateway located at Shannon airport. Aer Lingus started to use the marketing slogan "arrive before you depart" to promote the facility.

The impact of Aer Lingus' underpinning focus on connectivity between the UK and Dublin is evident in Figure 5 as it illustrates that it is continuously gaining momentum and that it is a scalable business enterprise - there is particularly strong growth from 2012 onwards. The high frequency to Heathrow coupled with using the connecting time to clear US immigration has triggered a CAGR of 35\% of passengers who connected in Dublin from 2011 to 2015. Birmingham, Cardiff, Edinburgh, Gatwick all registered over 34\% CAGR over the same period with Bristol recording 51\% growth. The partnership with Stobart Air and the resultant development of a hub to cater for UK to US traffic has been an integral part Aer Lingus' strategic evolution and one of the key synergies driving the IAG takeover bid for Irish incumbent (Tarry, 2015).

\section{Insert Figure 5}

\section{An analysis on Aer Lingus' connectivity between Newcastle and the US}

The Newcastle route illustrates the effectiveness of Aer Lingus' new connectivity business model. The North of England route was introduced in October 2013 and is operated twice daily by an ATR 72 aircraft offering 68 seats. Departures from Dublin are offered at 06:50 and 17:30 with the return flights departing Newcastle at 08:30 and 19.10. On the outbound morning service from Dublin to Newcastle during 2015, the flight can accept connections from 5 inbound US transatlantic flights. The shortest connection is 80 minutes while the longest connection is 105 minutes. On the return flight from Newcastle to Dublin, connections are possible to 6 outbound US cities, with the connecting service to New York 
being just 70 minutes. Bootsma (1997) and Burghouwt (2007) claim that a 2-hour minimum connection time between a European and a continental destination is considered 'excellent', thus Aer Lingus can extrapolate that its connection quality is a highly attractive proposition for such travellers. However, the Toronto departure time of 13:50 results in a 4 hour 10 minute connection time which is an unattractive option for the customer. This design targets passengers travelling on thin markets where the traffic volume is not sufficient for non-stop flights. Table 4 gives a snapshot of the penetration of Aer Lingus' connecting passenger market between Newcastle and North America through its Dublin hub over a 21 month period between 2013 and 2015. It shows a marked increase in the number transferring, particularly noticeable during the peak summer months, where around 14 passengers per day used Aer Lingus' morning flights to connect onwards by mid 2014 - this represented over one-fifth of the capacity of Stobart Air's ATR-72 aircraft of 68 seats. The San Francisco and Toronto flights were inaugurated in early 2014 but quickly gained traction while the Canadian destination outpaced San Francisco due to its daily operation. The lower frequency to San Francisco with 5 flights per week and Orlando with 3 services per week in 2014 had negatively impacted the connectivity permutation with Doganis (2014) arguing that passengers seek airlines with daily operations to facilitate their own life schedule.

This type of strategy was to be replicated across other UK regional airports as the flag carrier instigated advertising campaigns to create awareness of connection possibilities to the US that captured its pre-clearance in Dublin together with its favourable geographical location with Ireland being 'Stateside'. The Telegraph (2013) stated that there had been a paradigm shift in passengers from Northern England and Scotland favouring the Dublin hub, reporting a $36 \%$ year on year growth for UK originating and connecting passengers.

Insert Table 4

Aer Lingus scaling up its European connectivity portfolio

Aer Lingus also replicated its connectivity model across to other European markets such as Germany, where Lufthansa had approximately $51 \%$ of the 11 million passengers between the US and Germany in 2014, followed by its Star alliance partner United Airlines with almost 19\% (US Bureau of Transportation Statistics, 2015). Aer Lingus' earlier hub had a poorly 
planned schedule that was totally inadequate to facilitate fifth freedom traffic from German originating destinations to connect onwards to the US via Dublin. The carrier for example operated a mid-day flight from Hamburg four times a week from summer 2009 through to summer 2011, thereafter increasing to daily, but it was not sequenced to co-ordinate with any US bound flights - to build a meaningful connection, the departing flight must start within a connecting window. For the following summer season the flight was switched to a morning service which created many connecting options to multiple US cities. MIDT data revealed that 3,656 passengers travelled to/from Hamburg to the US by connecting through Dublin in 2014, generating \$1.8 million for Aer Lingus. Similarly Berlin's schedule was also tweaked by rescheduling the mid-day departure to an early morning and as a consequence the number of passengers transiting onto the North Atlantic increased 2.5 fold over a 3 year period to over 4,000 passengers by 2014. The numbers connecting from Dusseldorf, Frankfurt and Munich also continue to rise and these routes have double daily, morning and evening frequencies.

Mueller (2014) reported that transfer passengers from the UK and other parts of Europe made up almost one-third of Aer Lingus' long-haul traffic to North America. MIDT data for 2014 revealed that Aer Lingus transferred the following number of passengers (together with revenues generated) to/from its Dublin hub: UK, 94,468 (\$57.2 million); Italy, 33,868 (\$20.7 million); France, 30,619 (\$19.6 million); Spain, 23,324 (\$13.8 million); Germany, 21,019 (\$12.1 million); Netherlands, 15,050 (\$8.9 million); Belgium, 6,655 (\$3.8 million); Switzerland, 4,557 (\$2.9 million). Fagan (2015) emphasised that the strength of the connecting traffic allowed for the introduction of double daily flights on the Chicago, Boston and New York routes. Clearly, the traffic leakage from these economically prosperous European countries through Aer Lingus' re-engineered hub triggered IAG to incorporate the Irish flag carrier and enlarge its North Atlantic footprint (Walsh, 2015).

Aer Lingus' Hub by 2015 - its Evolution

Aer Lingus' competitive position is illustrated in the framework of a BCG matrix, which is an analytical tool that measures the dimensions of the carrier's relative market share against market growth rates as displayed in Figure 6. The data was extracted over 12 months for 2015 to smoothen seasonality factors. The attractiveness and competitiveness of the growing Ireland - North American market is clear as the Irish incumbent is 4.2 times stronger than 
United Airlines, its nearest challenger. The matrix classifies it as a 'Star' market. It allocates the most seats $(36 \%)$ to the UK market but it remains a follower due to Ryanair's dominance - this position has actually aided Aer Lingus as other carriers are not aggressively pursuing the market or absent (e.g. easyJet), while its principle differentiator, being its synchronising capability to incorporate seamless transfers with short connection times, which gives the passenger a different proposition from that of Ryanai

r. Aer Lingus is also the leader on the Ireland - Western Europe corridor which is growing at the CAGR of 3.3\%, while its Eastern European presence is negligible as Ryanair dominates with 4.7 times more seat capacity. This BCG snapshot illustrates the potential for evolving the Aer Lingus' hub. Barrett (2015) listed the iconic North Atlantic Brand, US pre-clearance and the neglect of UK regions by BA as the key success factors to Dublin's hub.

\section{Insert Figure 6}

By 2015 the bank structure had evolved considerably as shown in Figure 7, its partnerships had facilitated more frequencies and encompass a wider network penetration. It tightened the co-ordination of the hub timetable in order to reduce the airport dwell time which creates an overall flight time as close as operationally possible to that of a non-stop schedule. Seredyński et al. (2014) found from analysing worldwide MIDT data that $85 \%$ of their sample passengers booked the fastest connections, while $13 \%$ book the second-fastest connections. The hub is extremely effective for passengers travelling from North America into the UK and Europe as the network is fully synchronised for seamless transfers with short connection times. Meanwhile the hub for UK passengers taking westbound flights is also very effective, but it is not fully optimised for mainland European flights as these westbound flights arrive into Dublin after the first wave of transatlantic aircraft have departed and travellers become burdened with a much longer dwell time before they can connect to the second wave. Fagan (2015) states that this spread is necessary as it forces European passengers onto the second wave as aircraft from the first wave are already reaching maximum capacity from passengers connecting from the UK. To circumnavigate this dilemma, Aer Lingus would need to park an aircraft with crews overnight at mainland European airports at significant cost as this would become necessary in order to synchronise with the early wave. OAG analysis reveals that by 2015, Aer Lingus now offered 81 weekly summer flights to North America ${ }^{11}$ and commanded over $42 \%$ of the seat capacity out of 
Ireland, while out of its Dublin hub, it held 44\%. By 2015, Dublin airport had become the $7^{\text {th }}$ largest European gateway to North America, primarily due to Aer Lingus.

\section{Insert Figure 7}

\section{Conclusion}

Aer Lingus's 80 year old story is unique - it has been an essential economic link for an Island nation on the periphery of Europe, despite being immersed in financial difficulties on numberous occasions. It is the world's only carrier to transform from a full service to a low cost and then into a hybrid. It cohabitated with the world's most aggressive low cost carrier with unit costs $50 \%$ lower than Aer Lingus and who instigated a hostile buyout on three occasions but yet it has survived and prospered using the Value Hybrid model. Its transformed business model then became an attractive proposition for an IAG acquisition. This paper investigated the strategies that were put in place to structurally re-engineer the carrier.

Analytical insights accompanied by expert interviews uncovered four principle strategies that restructured Aer Lingus' business model. Firstly, it has an inherent seasonality contention and it became unwavering in its capacity discipline, which had the dual impact of stronger yields and high load factors. Secondly, like other airlines across the globe, it continued to trim its cost base while improving productivity and efficiency measures; however it did so in tandem with product enhancements that reached out to a wider passenger segmentation. Thirdly, as an independent carrier, it formulated a series of partnerships with select carriers that reached beyond its key gateways, while it also adopted a dual approach to its capacity management by outsourcing aircraft on a wet lease basis, without commercial risk, while insourcing capacity outside its own aircraft metal. It fabricated a paradigm franchise with Stobart Air that had the network footprint that penetrated small UK regional airports, which would be an essential building block for feed traffic to Aer Lingus. Fourthly and most critically, it structurally re-engineered its hub at Dublin airport. The objective was to create a 'focused' strategy whereby it created a seamless network linkage from the UK/Europe via Dublin onto the North Atlantic taking full advantage of Ireland's geography as the most westerly European country. Mueller (2014) concured that the restructured hub became the underpinning formula for Aer Lingus' turnaround and a pivotal facet of its 
strategic sucess. Aer Lingus was incorporated into IAG on $2^{\text {nd }}$ September 2015. Doganis (2014) suggests that this research could be used as a blueprint for struggling mid-sized airlines that are 'stuck in the middle' and to provide a roadmap to become a commercially viable enterprise.

\section{Endnotes}

1. For academic literature pertaining to Airline hybrid models refer to: Fageda et al. (2015);Dobruszkes (2013); Klophaus et al. (2012); Fageda et al. (2011); Franke and John (2011); Fageda and Fernandez-Villadangos (2009); Graham (2009); Mason and Morrison (2008).

2. The Troubles in Northern Ireland began in 1969, intensifying a conflict that had been ongoing since the partition of Ireland in 1920. The level of violence grew rapidly in the 1970s, peaking in 1972 when there were close to 500 deaths. In total, roughly 3,500 lives have been lost in the conflict (Dorsett, 2013).

3. Prior to its initial public offer (IPO) Aer Lingus was owned by the Irish Government (85\%) and its Employee Share Ownership Trust ESOT (15\%). The IPO of Aer Lingus took place on 2 October 2006, and the shares were listed on Dublin and London stock exchanges. Aer Lingus priced its IPO at $€ 2.20$ a share valuing the company at $€ 1$.1billion (The Telegraph, 2006).

4. Aer Lingus's pension deficit was estimated by the actuary to be $€ 336$ million in 2005 , but escalated to $€ 715$ million by 31 December 2013 (Irish Times, 2005; Aer Lingus, 2013, page $33)$.

5. Ryanair launched 3 hostile takeover bids for for the entire issued share capital of Aer Lingus. The first one occurred on $5^{\text {th }}$ October 2006 and was blocked by the EU Commission Article 4 of Council Regulation 139/2004 - EU General Court case T-342/07. The Commission deemed that the acquisition would pose significant competition issues on 46 routes out of Ireland. At Dublin airport, 35 European routes would overlap and the proposed merger would create a monopoly on 22 of these routes, while for the 13 other routes, the carriers were each other's closest competitors - the merged entity would be dominant with market shares of around $80 \%$ of all intra-European traffic from Dublin (European Commission, 2010). On $1^{\text {st }}$ December 2008, a $2^{\text {nd }}$ hostile bid was initiated, but abandoned 
after antitrust concerns together with claims by the Irish Government, that the proposed bid undervalued Aer Lingus. Ryanair's $3^{\text {rd }}$ takeover attempt took place on $19^{\text {th }}$ June 2012, but the European Commission outrightly prohibited it as it found that the market share of short-haul flights out of Dublin by the proposed merger would increase from $80 \%$ in 2007 , to $87 \%$ by 2012. It would harm consumers by reducing choice and lead to increased prices for passengers travelling in and out of Ireland - COMP/M.6663, EC no 139/2004 (European Commission, 2013). In addition, the UK Competition Authority (2015) concluded on $12^{\text {th }}$ February that Ryanair's $29.8 \%$ shareholding is anti-competitive and that it must sell it down to no more than $5 \%$.

6. The Expert interviewee's composed of: Dermot Mannion, ex CEO of Aer lingus; Enda Corneille, Former Director of Corporate Affairs at Aer Lingus and now Emirates country manager (Ireland); Simon Fagan, Director of Network Planning, Aer Lingus; Rigas Doganis, visiting Professor Cranfield University; Dr Sean Barrett, Economics Department, Trinity College Dublin; Dr Siobhan Tiernan, Course Director MBA(Aviation), University of Limerick; Patrick Edmond Group Strategy Director of International Aviation Services Centre, Shannon; Chris Tarry, Principle at CTAIRA. Giovanni Bisignani, ex CEO of IATA. The authors also posed questions to Christoph Mueller the 'Future of Air Transport' conference in London and to Willie Walsh, CEO of IAG who delivered a lecture at Cranfield University, UK.

7. This $€ 97$ million cost reduction would come from: Pilots $€ 30$ million; Cabin crew; $€ 20$ million; Support staff, $€ 16$ million; Airport charges, $€ 10$ million; Other staff, $€ 9$ million; Non-other staff costs, €4 million; Advertising, €3 million; Distribution, €3 million; and Maintenance, $€ 2$ million (Source: Aer Lingus corporate).

8. This is an efficient means of co-coordinating incoming 'spoke' traffic with departing flights at a carriers' home base. The strategy involves combining point-to-point traffic with transferring passengers originating from the points at the end of each spoke of the hub. Whereas the point-to-point traffic terminates at the hub, the transferring passengers pass through and depart to other domestic or international destinations on the hub's spoke network. The science involves the synchronisation of incoming flights to provide maximum feed for departing aircraft waiting to take-up their multi-origin share of incoming passengers. This form of scheduling creates a bank of many incoming flights arriving almost simultaneously, followed by a wave of departures. This method serves as an effective traffic multiplier. 
9. The Air Passenger Duty (APD) Tax is excessive, as a journey from the UK to the US West Coast for the summer of 2014 would induce a tax ranging from $£ 69$ to $£ 170$ GBP (UK Government, 2015).

10. Terminal 2 opened in November 2010 with an area of $75,000 \mathrm{~m}^{2}$ at a construction cost of $€ 923$ million. It increases the airport's passenger capacity to more than 30 million passengers a year. All of the long-haul carriers have moved to T2, including Aer Lingus to where it relocated all of its mainline operations (Dublin Airport, 2015; Irish Times, 2013).

11. From Ireland (Dublin and Shannon airports), in the summer of 2015, Aer Lingus operated 74 flights a week to the US and commanded $46.2 \%$ seat capacity market share, while it offered 7 services a week to Canada but held just 20.5\% market share. Out of Dublin, Aer Lingus operated 61 flights a week to the US with $49.1 \%$ market share, while to Canada it conducts 7 flights a week with a $17.7 \%$ market share (Source: OAG data).

\section{References}

ADV, 2015. German airport statistics, accessed at http://www.adv.aero/home/

Aer Lingus, 2002. Aer Lingus Annual Report 2002, Dublin: Aer Lingus.

Aer Lingus, 2009. Aer Lingus Annual Report 2009, Dublin: Aer Lingus.

Aer Lingus, 2010. Aer Lingus Annual Report 2010, Dublin: Aer Lingus.

Aer Lingus, 2011. Aer Lingus Annual Report 2011, Dublin: Aer Lingus.

Aer Lingus, 2012. Aer Lingus Annual Report 2012, Dublin: Aer Lingus.

Aer Lingus, 2013. Aer Lingus Annual Report 2013, Dublin: Aer Lingus.

Aer Lingus, 2014. Aer Lingus Annual Report 2014. Dublin: Aer Lingus.

Aviation Economics, 2016. Analysis of airport chaqrges - Airlines 4 Europe, version 1.4, January, accessed at http://a4e.eu/wp-content/uploads/2015/02/AvEc-Airport-ChargeAnalysis-v1.5.pdf

Barrett, S., 2015. Author Interview through email, March $19^{\text {th }}$

Barrett, S., 2006. Commercialising a national airline - the Aer Lingus case study. Journal of Air Transport Management 3(2), 159-167.

Barrett, S., 1997. The implications of the Ireland - UK airline deregulation for an EU internal market. Journal of Air Transport Management 12(4), 67-73. 
Bilotkach, V., 2007. Complementary versus semi-complementary airline partnerships, Transportation Research Part B: Methodological 41 (4), 381-393

Bisignani, G., 2013. Author question posed to ex CEO of IATA, Cranfield Univeristy, $10^{\text {th }}$ September .

Boeing Current Market Outlook, 2015. Accessed at http://www.boeing.com/resources /boeingdotcom/commercial/about-our-market/assets/downloads/Boeing_Current_Market_Out look_2015.pdf

Bootsma, P., 1997. Airline flight schedule development; analysis and design tools for European hinterland hubs. Utrecht, University of Twente (PhD thesis),

Brueckner, J.K., Proost, S. 2010. Carve-outs_under_airline antitrust immunity, International Journal of Industrial Organization, 28 (6), 657-668

Burghouwt, G., de Wit, J., 2005. Temporal configurations of airline networks in Europe. Journal of Air Transport Management 11(3), 185-198.

Burghouwt, G., 2007. Airline Network Development in Europe and its Implications, Aldershot, Ashgate.

Buyck, C., 2009. Aer Lingus facing 'most difficult period' in its history, June $7^{\text {th }}$, Air Transport World, accessed at http://atwonline.com/news/aer-lingus-facing-most-difficultperiod-its-history

CAPA, 2009. Aer Lingus employees should prepare for "amputation" amid cost cuts., September $18^{\text {th }}$, accessed at http://centreforaviation.com/news/aer-lingus-employees-shouldprepare-for-amputation-amid-cost-cuts-22075

CAPA, 2013. Aer Lingus A330 to operate charters for Kuoni Scandinavia in winter 2013/2014, April 13 ${ }^{\text {th }}$, accessed at http://centreforaviation.com/news/aer-lingus-a330-tooperate-charters-for-kuoni-scandinavia-in-winter-20132014-225845

Corneille, E., 2015. Author interview with Former Director of Corporate Affairs at Aer Lingus, Dublin, March $16^{\text {th }}$

Cronin, M., 2011. Doesn't Time Fly? Aer Lingus - Its History, Cork, The Collins Press.

Denton N., Dennis N., 2000. Airline franchising in Europe: benefits and disbenefits to airlines and consumers. Journal of Air Transport Management 6, 179-190. 
De Wit, J., Zuidberg, J., 2012. The growth of the low cost carrier model, Journal of Air Transport Management 21, 17-23.

Dobruszkes, F., 2013. The geography of European low-cost airline networks: a contemporary analysis, Journal of Transport Geography 28, 75-88.

Dobruszkes, F., Van Hamme, G., 2011. The impact of the current economic crisis on the geography of air traffic volumes: an empirical analysis, Journal of Transport Geography 19 (6), 1387-1398

Doganis, R., 2104. Author interview with visiting Professor at Cranfield Univeristy, Cranfield, July $5^{\text {th }}$

Doganis, R., 2001. The Airline Business in the 21st Century. Routledge, London.

Dorsett, R., 2013. The effect of the Troubles on GDP in Northern Ireland, European Journal of Political Economy, 29, 119-133

Dublin Airport, 2015. Dublin Airport latest news, accessed at http://www.dublinairport.com/gns/at-the-airport/latest-news.aspx

European Commission, 2013. Ryanair/Aer Lingus III, Merger proposal, 27 ${ }^{\text {th }}$ February, accessed at http://ec.europa.eu/competition/mergers/cases/decisions/m6663_9077_1.pdf

European Commission, 2010. MEMO/10/300, Mergers: Commission welcomes General Court rulings in Ryanair case, Brussels, $6^{\text {th }}$ July, accessed at http://europa.eu/rapid/press release_MEMO-10-300_en.htm

Fagan, S., 2015. Author interview with Director of Network Planning at Aer Lingus, Dublin, $11^{\text {th }}$ March

Fageda, X., Fernandez-Villadangos, L., 2009. Triggering competition in the Spanish airline market: the role of airport capacity and low cost carriers. Journal of Air Transport Management 15, 36-40.

Fageda, X., Jimenez, J.L., Perdiguero, J., 2011. Price rivalry in airline markets: a successful strategy of a network carrier against a low-cost carrier, Journal of Transport Geography 19, 658-669.

Fageda, X., Suau-Sanchez, P., Mason, K. 2015. The evolving low-cost business model: Network implications of fare bundling and connecting flights in Europe Journal of Air Transport Management, 42, 289-296 
Franke, M., John, F., 2011. What comes next after recession? Airline industry scenarios and potential end games. Journal of Air Transport Management 17, 19-26.

Graham, M., 2009. Different models in different spaces or liberalized optimizations? Competitive strategies among low-cost carriers, Journal of Air Transport Management 16, 127-136.

House of the Oireachtas, 1993. Aer Lingus Statements, $13^{\text {th }}$ July, accessed at http://oireachtasdebates.oireachtas.ie/debates\%20authoring/debateswebpack.nsf/takes/seanad 1993071300006?opendocument

Irish Times, 2015. Heathrow slots key if IAG wants to get Aer Lingus deal airborne, $30^{\text {th }}$ January, accessed at http://www.irishtimes.com/business/transport-and-tourism/heathrowslots-key-if-iag-wants-to-get-aer-lingus-deal-airborne-1.2084294

Irish Times, 2005. Cullen urges review of pension deficit at Aer Lingus, December $3^{\text {rd }}$, accessed at http://www.irishtimes.com/business/cullen-urges-review-of-pension-deficit-ataer-lingus-1.1172277

Ideaworks, 2015. 2014 Airline Ancillary Revenue Activity Surpasses \$38 Billion, Up Nearly 21 Percent, $14^{\text {th }}$ September' accessed at http://www.ideaworkscompany.com/wpcontent/uploads/2015/09/Press-Release-100-Ancillary-Revenue-Yearbook.pdf

Irish Central Statistics Office, 2015. International Movement of Passengers by Air and Sea, accessed at http://www.cso.ie/Quicktables/GetQuickTables.aspx? FileName= TRBAC1.asp\& TableName =International $\% 20$ Movement $\% 20$ of $\%$ 20Passengers $\% 20$ (Number)\%20by\%20Air\%20and\%20Sea\&StatisticalProduct=DB_TM

Kaminski-Morrow, D., 2013. Aer Lingus leasing 757s to expand transatlantic routes, April $26^{\text {th }}$, accessed at http://dashboard.flightglobal.com/app/\#/articles/385204?context

Klophaus, R., Conrady, R., Fichert, F., 2012. Low cost carriers going hybrid: evidence from Europe, Journal of Air Transport Management 23, 54-58.

Mannion, D. 2015. Author Interview with Ex-CEO of Aer Lingus, by phone from Brunei, February $27^{\text {th }}$

Mason, K.J., Morrison, W.G., 2008. Towards a means of consistently comparing airline business models with an application to the low cost airline sector, Research in Transportation Economics 24, 75-84.

McCabe, S. 2015. A refreshed brand, revamped website and new routes: Aer Lingus takes flight under IAG, Irish Independent, $18^{\text {th }}$ October, accessed at http://www.independent.ie/business/irish/a-refreshed-brand-revamped-website-and-newroutes-aer-lingus-takes-flight-under-iag-34118171.html 
Moores, V., 2013. Still Fighting, Air Transport World 50(11), November, 36 -41.

Mueller, C., 2014. Conference discussion by Aer Lingus' CEO, Future of Air Transport Conference, Marketforce, London, December 2-3.

O'Connell J.F., 2015. Anti Trust Immunity cartel on the North Atlantic, Restricting the skies: The end of airline liberalisation?, European Aviation conference, Cranfield Univeristy, 19 20 November.

O'Connell, J. F., 2007. The strategic response of full service airlines to the low cost carrier threat and the perception of passengers to each type of carrier, $\mathrm{PhD}$ thesis, Cranfield University.

O'Connell, J.F. and Williams, G., 2005. Passengers' perceptions of low cost airlines and full service carriers: A case study involving Ryanair, Aer Lingus, Air Asia and Malaysia Airlines, Journal of Air Transport Management 11(4), 259-272.

Share, B., 1986. The Flight of the Iolar, The Aer Lingus Experience, 1936-1986. Gill and Macmillan, Dublin.

Skinner, M. and Cranitch, T., 1990. Ireland and World Aviation: The Complete Story. Director Publications, Dublin.

Suau-Sanchez, P., Voltes-Dorta, A., Rodríguez-Déniz, H., 2016. The role of London airports in providing connectivity for the UK: regional dependence on foreign hubs, Journal of Transport Geography, 50, 94-104

Seredyński, A., Rothlauf, F., Grosche, T., 2014. An airline connection builder using maximum connection lag with greedy parameter selection Journal of Air Transport Management, 36, 120-128

Tarry, C., 2015. Author interview with Principal at CTAIRA, $16^{\text {th }}$ March

The Telegraph, 2013. Dublin airport 'an alternative hub to Heathrow', says Aer Lingus, $3^{\text {rd }}$ July, accessed at http://www.telegraph.co.uk/finance/newsbysector/transport/10158483/ Dublin-airport-an-alternative-hub-to-Heathrow-says-Aer-Lingus.html

The Telegraph, 2006. Aer Lingus IPO takes off, $27^{\text {th }}$ September, accessed at http://www. telegraph .co.uk/finance/2947951/Aer-Lingus-IPO-takes-off.html

Tiernan, S., 2015. Author with with course director MBA, (Aviation Management Stream), University of Limerick, March $10^{\text {th }}$

UK CAA, 2015. Data and analysis, accessed at https://www.caa.co.uk/Data-and-analysis/ 
UK Competition Authority, 2015. CMA welcomes Court of Appeal Judgment on Ryanair/Aer Lingus, $12^{\text {th }}$ February, accessed at https://www.gov.uk/government/news/cmawelcomes-court-of-appeal-judgment-on-ryanairaer-lingus

UK Government, 2015. Rates and allowances: Excise Duty - Air Passenger Duty, April $6^{\text {th }}$, accessed at https://www.gov.uk/government/publications/rates-and-allowances-excise-dutyair-passenger-duty/rates-and-allowances-excise-duty-air-passenger-duty

US Bureau of Transportation Statistics, 2015. T-100 Statistics, accessed at http://www.rita.dot.gov/bts/data_and_statistics/index.html

Waldron, R., 2016. The "unrevealed casualties" of the Irish mortgage crisis: Analysing the broader impacts of mortgage market financialisation, Geoforum 69, 53-66.

Wallace, J., Tiernan, S., White, L., 2006. Industrial Relations Conflict and Collaboration: Adapting to a Low Fares Business Model in Aer Lingus, European Management Journal 24 (5), 338-347.

Weldon, N., 2002. Pioneers in Flight: Aer Lingus and the Story of Aviation in Ireland, Dublin: The Liffey Press.

Walsh, W., 2015. Lecture by IAG CEO, Cranfield University, $5^{\text {th }}$ November 


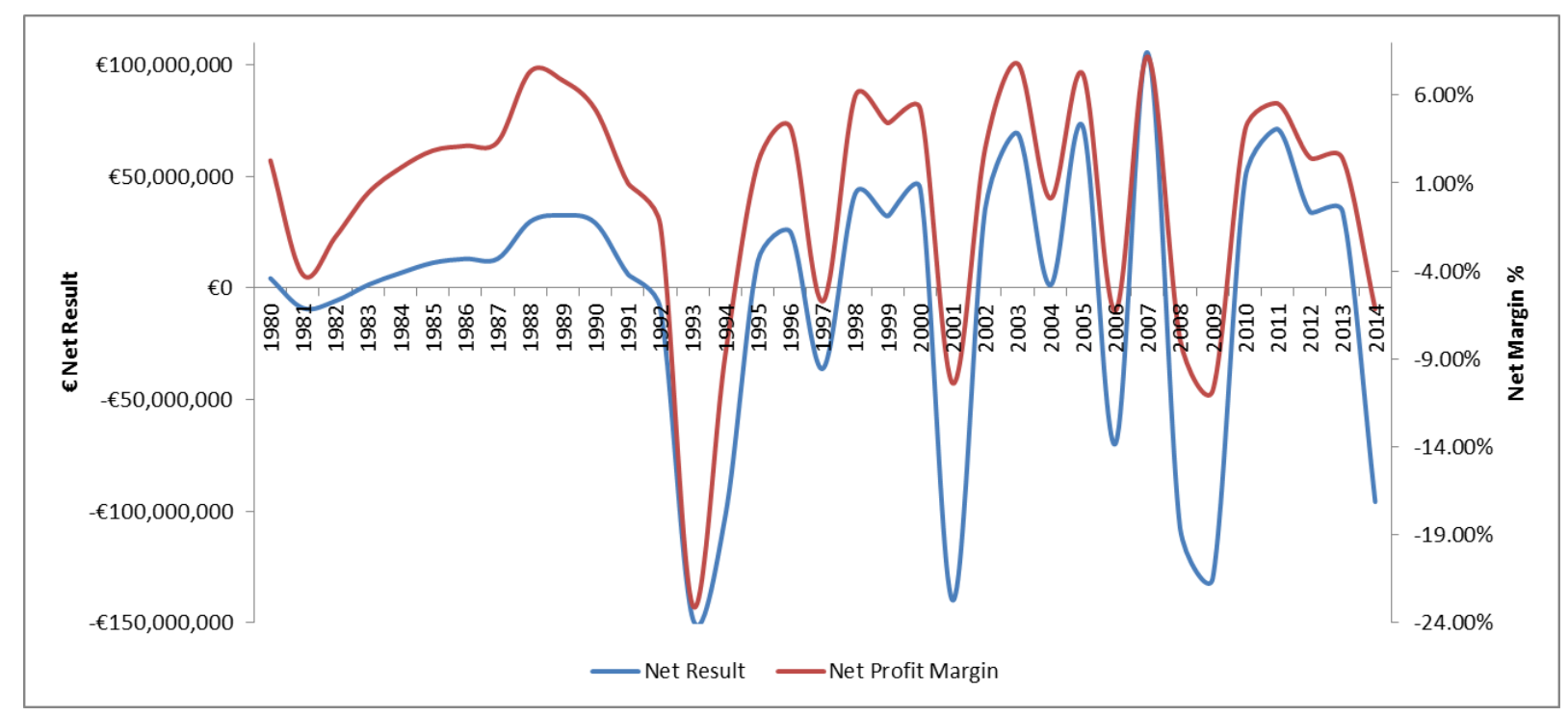

Figure 1. Aer Lingus Net Profitability (1980-2013)

Source: Weldon (2002) and Aer Lingus Annual Reports 
Table 1. Aer Lingus positioning as a Value Hybrid airline

\begin{tabular}{|c|c|c|c|}
\hline Traits & $\begin{array}{c}\text { LCC } \\
\text { Ultra-LCCs }\end{array}$ & $\begin{array}{l}\text { Aer Lingus } \\
\text { 'Value' Hybrid }\end{array}$ & $\begin{array}{l}\text { Full Service } \\
\text { Flag Carriers }\end{array}$ \\
\hline Key Target & Price Sensitive & Combination of leisure & Business and premiv \\
\hline Audience & Leisure & and business & leisure \\
\hline Product Offering & $\begin{array}{l}\text { Basic Seat } \\
\text { Very limited paid } \\
\text { add-ons }\end{array}$ & $\begin{array}{l}\text { Quality core product plus } \\
\text { benefit driven a la carte } \\
\text { paid options }\end{array}$ & $\begin{array}{l}\text { Multiple product } \\
\text { attributes fully- } \\
\text { bundled }\end{array}$ \\
\hline Airport Selection & Secondary & Central & Primary \\
\hline \multirow{2}{*}{$\begin{array}{l}\text { Customer } \\
\text { engagement and } \\
\text { relationship mgt }\end{array}$} & \multirow[t]{2}{*}{ None } & $\begin{array}{l}\text { Natural Positive } \\
\text { Engagement }\end{array}$ & $\begin{array}{l}\text { Structured approach to } \\
\text { customer engagement } \\
\text { (one to one) }\end{array}$ \\
\hline & & $\begin{array}{l}\text { Standalone FFP with } \\
\text { selected reciprocity }\end{array}$ & Alliance based FFPs \\
\hline $\begin{array}{l}\text { Customer } \\
\text { Expectations }\end{array}$ & Low & Medium & High \\
\hline $\begin{array}{l}\text { Distribution } \\
\text { Channel }\end{array}$ & Internet Only & $\begin{array}{l}\text { Internet as priority but } \\
\text { multi-channel where } \\
\text { appropriate }\end{array}$ & $\begin{array}{l}\text { Multi-channel by } \\
\text { default }\end{array}$ \\
\hline $\begin{array}{l}\text { Network } \\
\text { Connectivity }\end{array}$ & None & $\begin{array}{l}\text { Appropriate connectivity } \\
\text { offering at selected hubs. } \\
\text { Emphasis on partnerships } \\
\text { and connectivity to other } \\
\text { airlines }\end{array}$ & $\begin{array}{l}\text { Complex connectivity } \\
\text { across several hubs }\end{array}$ \\
\hline Brand Image & Downmarket & $\begin{array}{l}\text { Professional but } \\
\text { affordable }\end{array}$ & Polished, upmarket \\
\hline $\begin{array}{l}\text { Airport \& online } \\
\text { check-in }\end{array}$ & Additional charge & No Charge & No charge \\
\hline Seat Selection & $\begin{array}{l}\text { Additional charge } \\
\text { for priority } \\
\text { boarding }\end{array}$ & $\begin{array}{l}\text { Majority of seats } \\
\text { available for free selection } \\
24 \text { hours in advance of } \\
\text { flight. Paid selection for } \\
\text { some in front of cabin }\end{array}$ & No charge \\
\hline
\end{tabular}

Source: Aer Lingus (2010, page 8) 


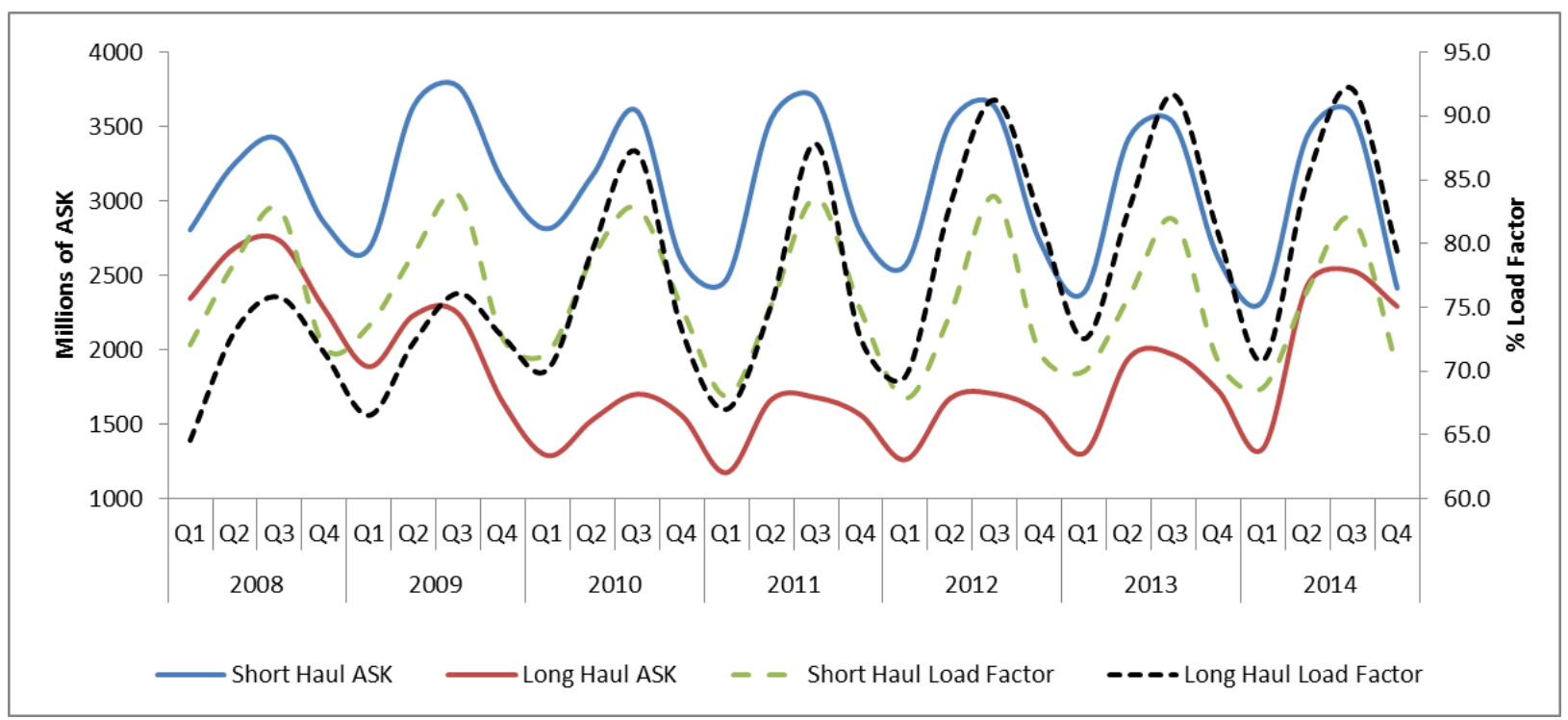

Figure 2. The evolution and interplay of Available Seat Kilometres and Load Factor (20082014)

Source: Traffic Statistics from Aer Lingus Corporate 


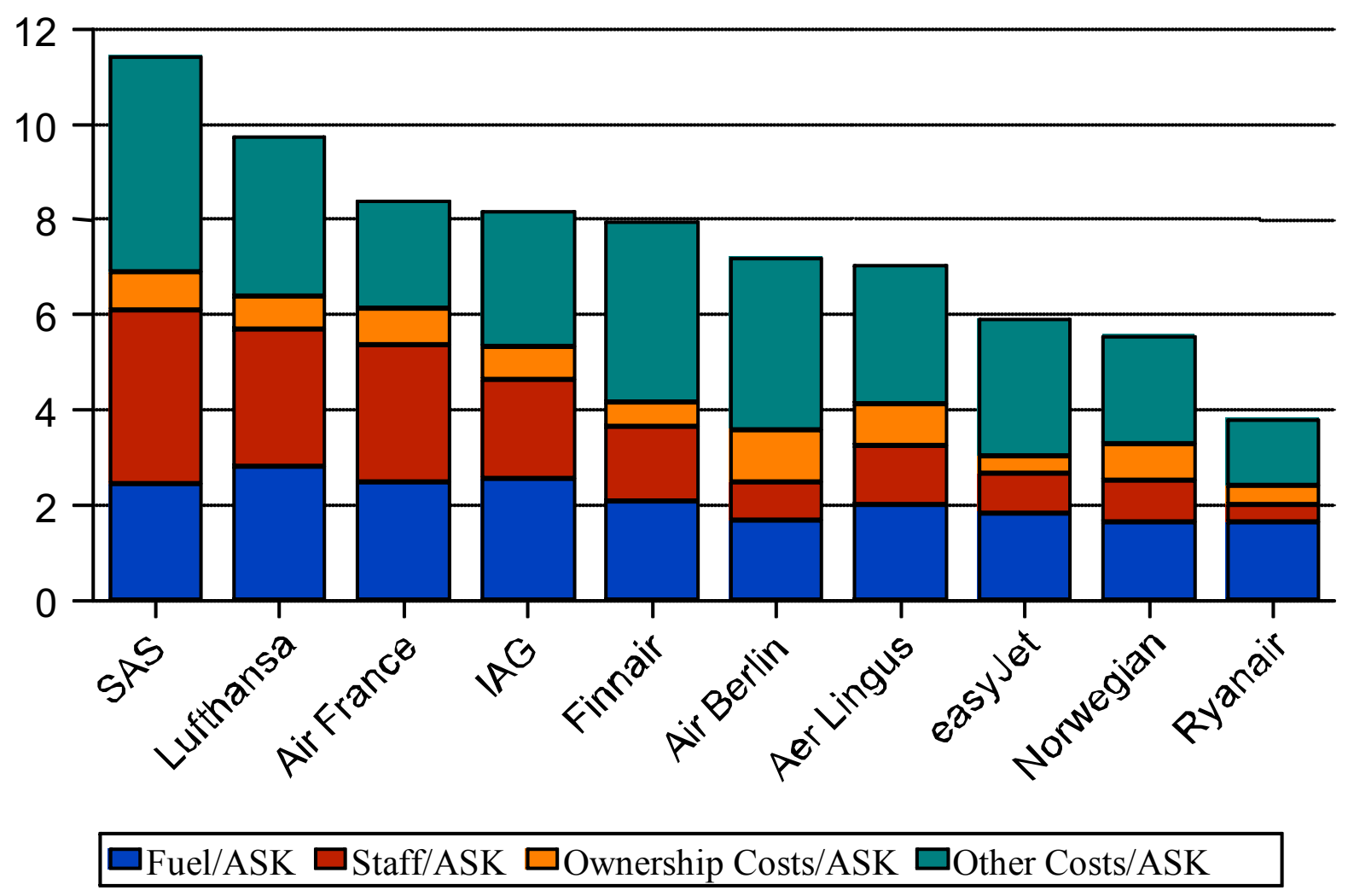

Figure 3. European Airlines Unit Cost per ASK (EURc) for 2014

Source: analysis from company data 
Table 2. Aer Lingus Operating Costs (CASK and RASK)

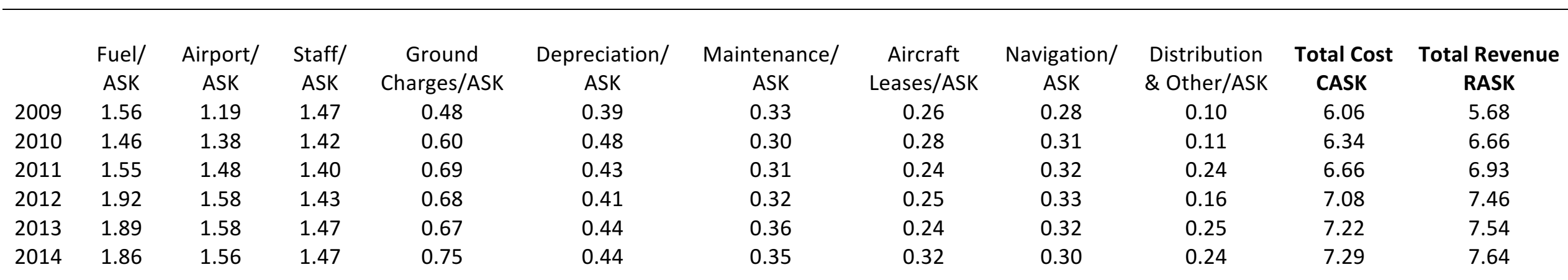

Source: Company accounts 


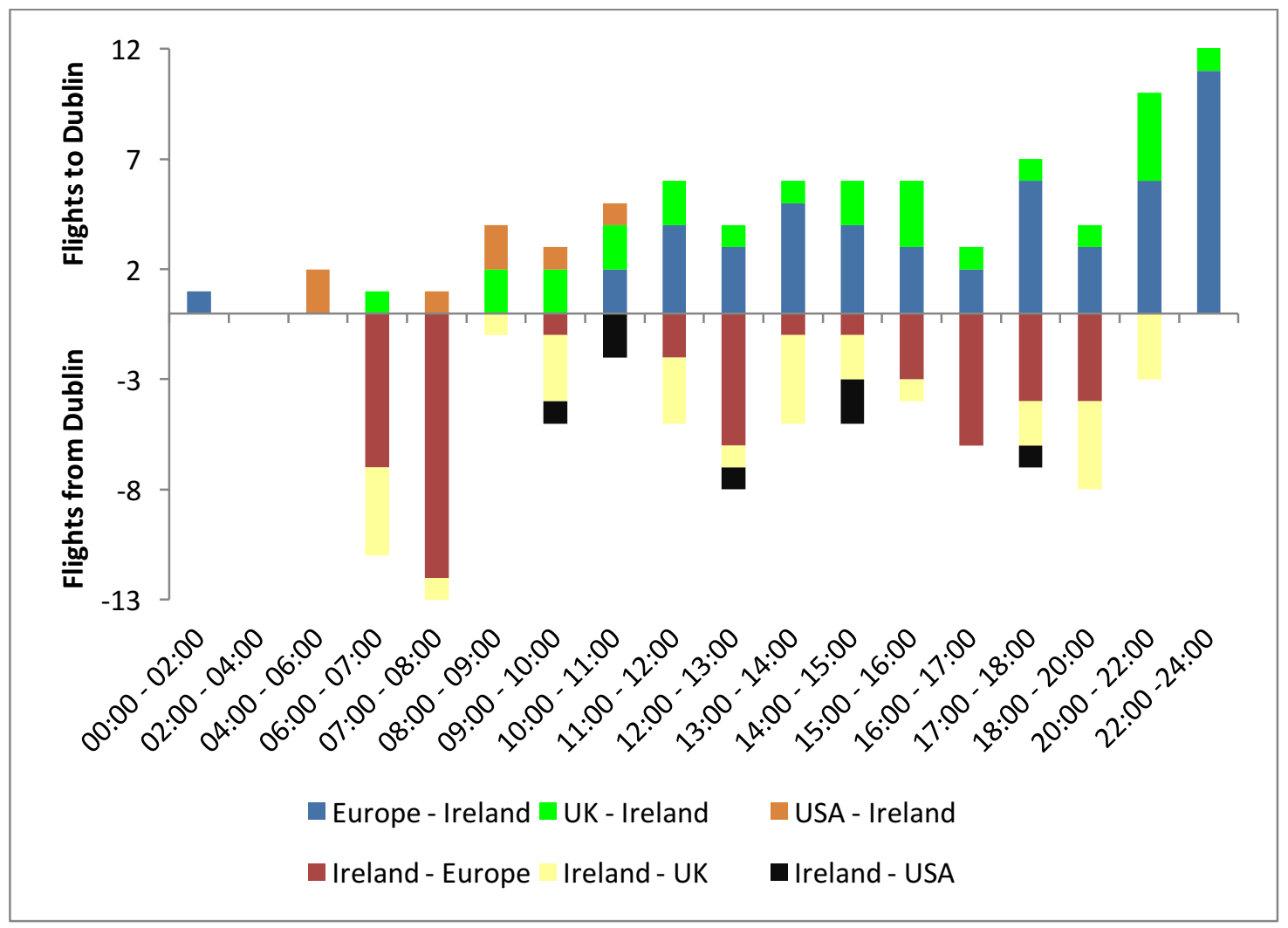

Figure 4. Aer Lingus bank Structure at Dublin (21st July 2008)

Source: OAG 


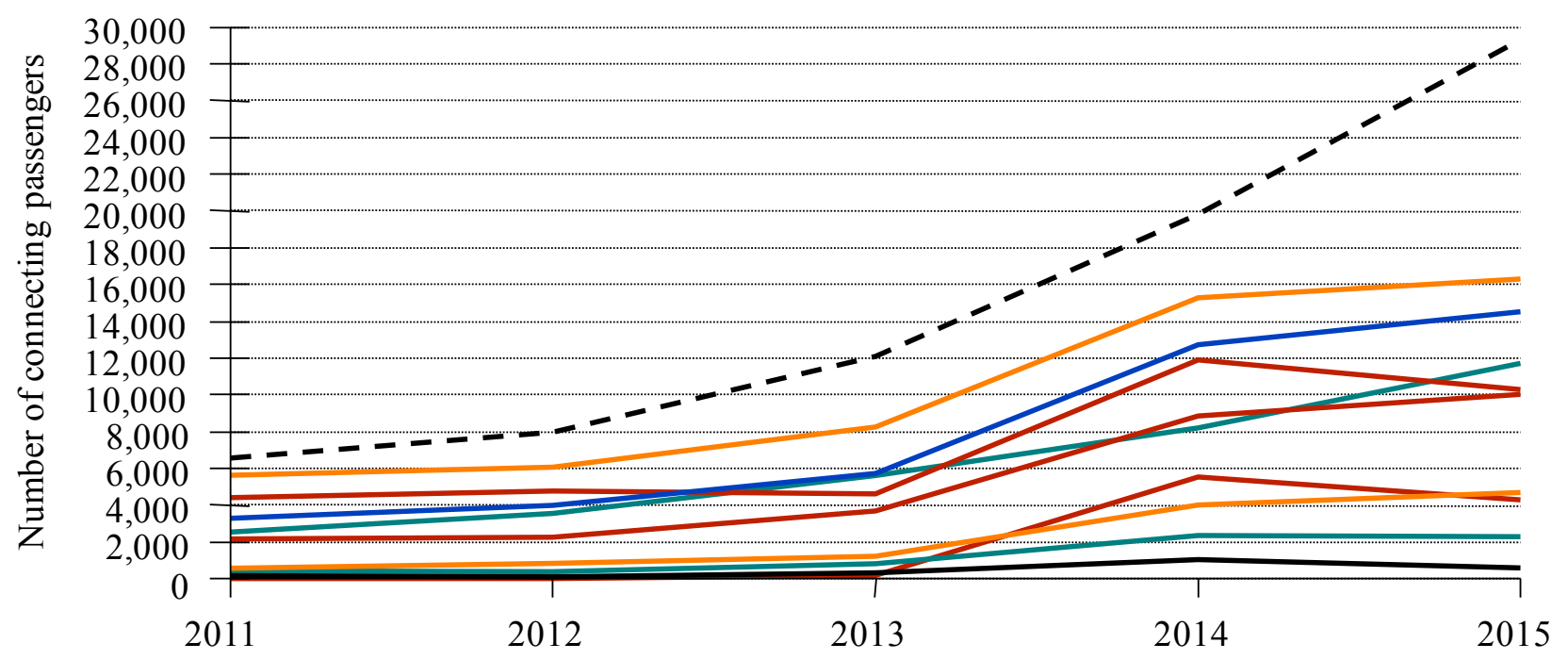

\begin{tabular}{|lllll}
\hline - Aberdeen & - Birmingham & - Bristol & - Cardiff & -Edinburgh \\
- Glasgow & - Manchester & - London Gatwick & - - London Heathrow & - Newcastle \\
\hline
\end{tabular}

Figure 5. The evolution of UK passengers travelling to/from the UK to the United States via Dublin airport with Aer Lingus (2011-2015)

Source: MIDT data 
Table 4. Connecting traffic between Newcastle and North America via Dublin on Stobart Air

\begin{tabular}{|c|c|c|c|c|c|c|c|c|c|c|c|c|c|c|}
\hline & \multicolumn{7}{|c|}{ North America to Newcastle } & \multicolumn{7}{|c|}{ Newcastle to North America } \\
\hline & $\begin{array}{l}\text { Q4 } \\
2013\end{array}$ & $\begin{array}{c}\text { Q1 } \\
2014\end{array}$ & $\begin{array}{c}\text { Q2 } \\
2014\end{array}$ & $\begin{array}{l}\text { Q3 } \\
2014\end{array}$ & $\begin{array}{c}\text { Q4 } \\
2014\end{array}$ & $\begin{array}{c}\text { Q1 } \\
2015\end{array}$ & $\begin{array}{l}\text { Q2 } \\
2015\end{array}$ & $\begin{array}{l}\text { Q4 } \\
2013\end{array}$ & $\begin{array}{l}\text { Q1 } \\
2014\end{array}$ & $\begin{array}{l}\text { Q2 } \\
2014\end{array}$ & $\begin{array}{l}\text { Q3 } \\
2014\end{array}$ & $\begin{array}{l}\text { Q4 } \\
2014\end{array}$ & $\begin{array}{l}\text { Q1 } \\
2015\end{array}$ & $\begin{array}{c}\text { Q2 } \\
2015\end{array}$ \\
\hline Boston & 19 & 68 & 160 & 221 & 132 & 67 & 107 & 29 & 57 & 157 & 237 & 109 & 58 & 89 \\
\hline New York JFK & 36 & 280 & 354 & 437 & 241 & 153 & 268 & 48 & 270 & 347 & 422 & 219 & 137 & 258 \\
\hline Orlando & 2 & 17 & 48 & 86 & 49 & 35 & 47 & 2 & 20 & 41 & 83 & 47 & 30 & 47 \\
\hline Chicago & 5 & 13 & 86 & 149 & 38 & 20 & 62 & 9 & 17 & 97 & 148 & 37 & 22 & 64 \\
\hline San Francisco & - & 3 & 51 & 69 & 36 & 19 & 51 & - & 5 & 59 & 79 & 37 & 35 & 60 \\
\hline Toronto & 3 & 4 & 111 & 182 & 75 & 44 & 99 & 5 & 2 & 115 & 186 & 75 & 36 & 105 \\
\hline $\begin{array}{l}\text { Origin or } \\
\text { Destination } \\
\text { beyond gateway }\end{array}$ & 23 & 35 & 106 & 128 & 49 & 35 & 77 & 22 & 33 & 92 & 127 & 50 & 53 & 82 \\
\hline Total & 88 & 420 & 916 & 1,272 & 620 & 373 & 711 & 115 & 404 & 908 & 1,282 & 574 & 371 & 705 \\
\hline $\begin{array}{l}\text { Frequencies } \\
\text { Offered (Morning } \\
\text { only) }\end{array}$ & 92 & 90 & 91 & 92 & 90 & 90 & 90 & 92 & 90 & 91 & 92 & 90 & 90 & 90 \\
\hline $\begin{array}{l}\text { Connecting } \\
\text { Passengers per } \\
\text { Frequency }\end{array}$ & 1 & 4.6 & 10.06 & 13.82 & 6.9 & 4.14 & 7.9 & 4.54 & 4.49 & 10 & 13.93 & 6.3 & 4.12 & 7.83 \\
\hline
\end{tabular}

Source: MIDT and OAG data 


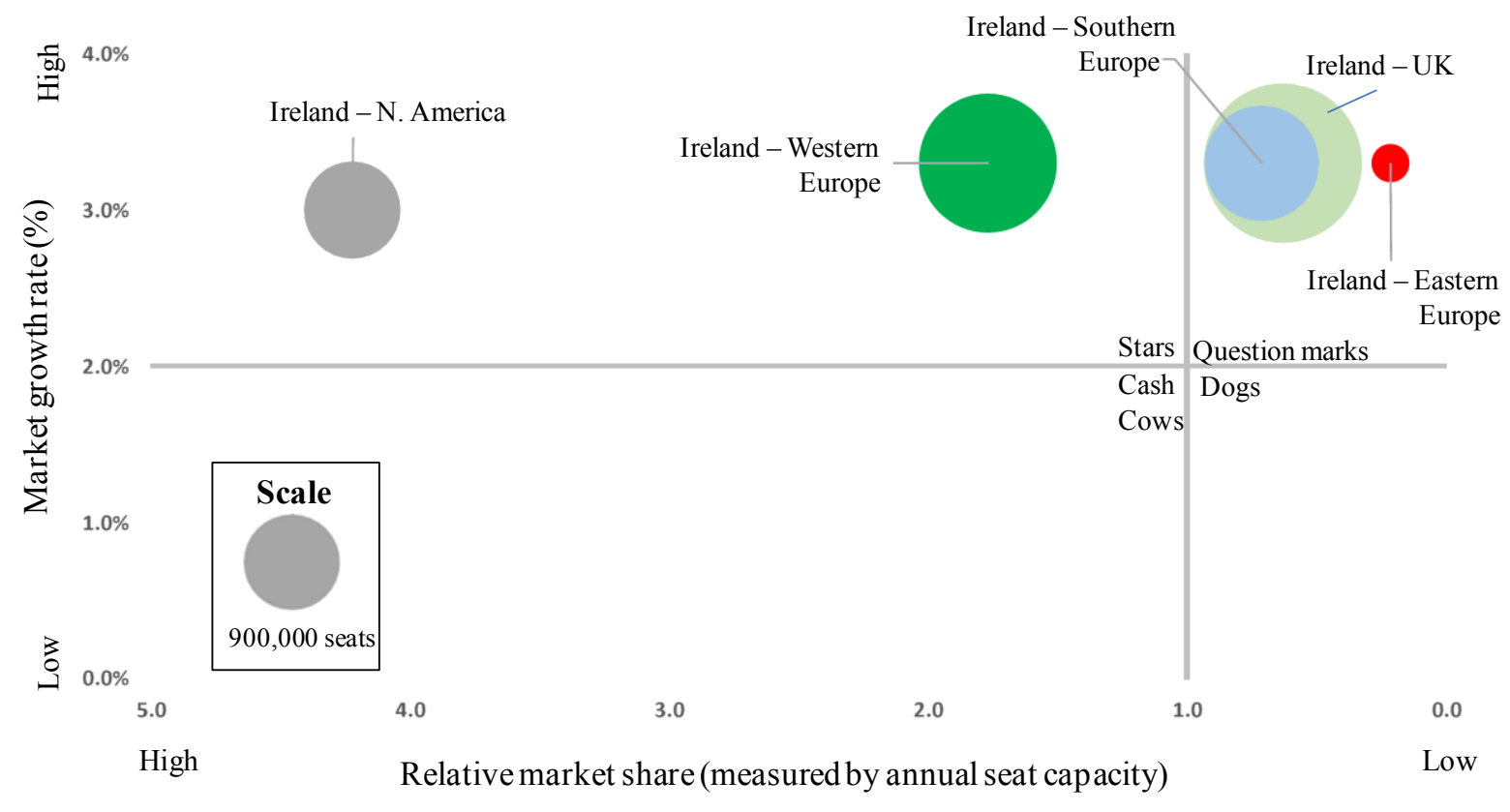

Figure 6. BCG Matrix for Aer Lingus for 2015 (January - December)

Source: OAG, MIDT, Boeing Current Market Outlook (2015)

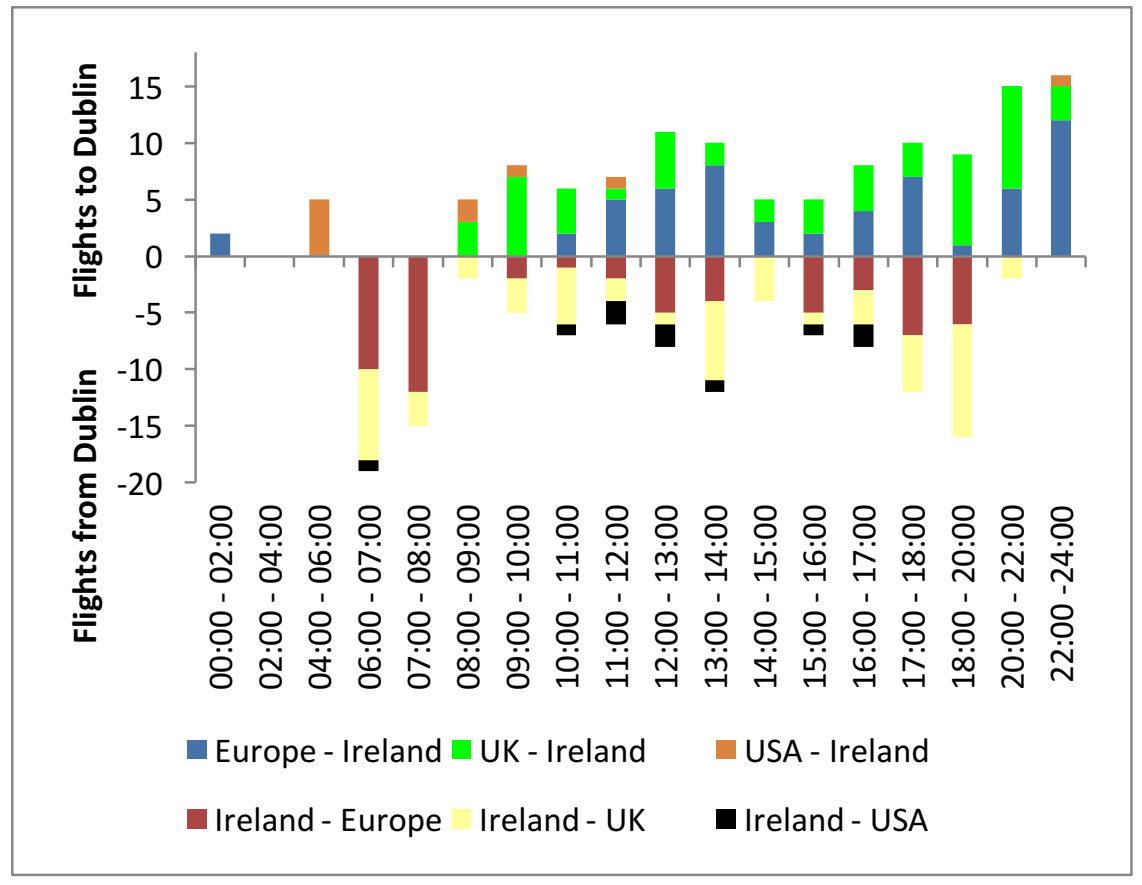

Figure 7. Aer Lingus bank Structure at Dublin (20 July 2015)

Source: OAG 
2016-12-20

The strategic evolution of Aer Lingus from a full-service airline to a low-cost carrier and finally positioning itself into a value hybrid airline

O'Connell, John F.

Sage

pÿO Connell JF, Connolly D, The strategic evolution of Aer Lingus from a full-service airline to a low-cost carrier and finally positioning itself into a value hybrid airline, Tourism Economics, pÿVolume 23, Issue 6, 2017, pp. 12961320

http://dx.doi.org/10.1177/1354816616683492

Downloaded from Cranfield Library Services E-Repository 